\title{
Metal provenancing using isotopes and the Oxford archaeological lead isotope database (OXALID)
}

\author{
Zofia Anna Stos-Gale • Noël H. Gale
}

Received: 27 March 2009/Accepted: 15 July 2009 /Published online: 21 August 2009

(C) Springer-Verlag 2009

\begin{abstract}
This paper reviews the research into the methodology of lead isotope provenance studies carried out at the University of Oxford between 1975 and 2002, at first in the Department of Geology (Geological Age and Isotope Research Laboratory), later in the Isotrace Laboratory based in the Department of Nuclear Physics, and eventually part of the Research Laboratory of Archaeology and the History of Art. These 27 years of intensive work, funded initially by the Stiftung Volkswagenwerk, and later from numerous UK Government and Charitable funds and finally by the Institute of Aegean Prehistory laid the foundations of the lead isotope provenance methodology and resulted in a large database of analytical isotope and elemental results. In spite of the efforts of the authors, this database is still not comprehensively published or easily accessible in a digital format by all researchers interested in using this method for their projects. The possibilities of advancing this situation are discussed. The authors discuss in detail the basic restrictions and advantages of using the lead isotope compositions of ores in mineral deposits for finding the origin of the raw materials used for making ancient artefacts. Methods for the scientific interpretation of the data are discussed, including attempts to use statistical methods. The methodology of creating the Oxford lead isotope database (OXALID) is outlined and a summary is given of the lead isotope resource provided by OXALID.
\end{abstract}

\footnotetext{
Z. A. Stos-Gale $(\bowtie)$

Ifold,

West Sussex, UK

e-mail: sophie@stos-gale.com

N. H. Gale $(\bowtie)$

Nuffield College,

Oxford, UK

e-mail: noel.gale@nuffield.ox.ac.uk
}

Keywords Lead isotopes · Tin isotopes · Copper isotopes · Archaeology · Provenance studies · Methodology . Interpretation $\cdot$ Statistics $\cdot$ Ore deposits $\cdot$ Metals trade . Bronze Age $\cdot$ Mediterranean

\section{Introduction}

From very early in the study of ancient metals, one important goal was to establish the geological origin of the metal used to make particular metal artefacts, thus, directly addressing issues of trade, trade relationships and movement of objects. Initially, the approach taken was through chemical analysis, beginning in 1934 (Noddack and Noddack 1934) and leading on to the large-scale chemical analytical programmes of Otto and Witter (1952) and the Stuttgart group (Junghans et al. 1960, 1968, 1974), conveniently reviewed by Härke (1978). Valuable though these studies were for establishing the development of metallurgy through time, they did not contribute much to establishing the metal ore sources used. Chemical analyses by themselves fail to provenance metals due to chemical heterogeneities in ore deposits and variable fractionation of chemical elements between ores, slag and metal in primitive smelting procedures, as discussed by Gale and Stos-Gale (1982, 2000).

With the widespread recognition that chemical analysis had failed as an approach to determining the geological origin of the metal used to make metal objects, two research groups independently suggested that this objective might be achieved instead by the comparative lead isotope analysis of artefacts and metal ores (Brill and Wampler 1965; Grögler et al. 1966). The Swiss group of Grögler et al. did not pursue this line of research further, while Brill and his colleagues continued to publish lead isotope analyses of 
glass, coins and other metal objects but did not advance the subject significantly because they failed to accompany their work on artefacts with the sufficiently extensive lead isotope analyses of metal ores that is also necessary.

Systematic studies and applications of lead isotope provenancing began in the 1970s when a group at the Max-Planck-Institut für Kernphysik in Heidelberg, comprising W. Gentner, G. A. Wagner and O. Müller, invited N. $\mathrm{H}$. Gale at the University of Oxford to join them in collaborative work. This resulted in several years of close collaboration between Oxford and Heidelberg, financed by grants from the Stiftung Volkswagenwerk and focused on studies of the provenance of ancient Greek silver coins using both trace element and lead isotope analysis. A new and central feature of this collaboration was the emphasis, beyond the analytical work, on extensive fieldwork on lead-silver deposits in and around the Aegean, involving geological and mining archaeological field work, as well as mineralogical studies of ores and metallurgical remains. A paper summarising the early stages of the lead isotope side of the project was presented at the 16th International Symposium on Archaeometry in Edinburgh in 1976 (Chamberlain and Gale 1980) whilst further papers resulting from this collaboration were presented at the 18th International Symposium on Archaeometry in Bonn in 1978 (Gale 1979; Muller and Gentner 1979; Wagner and Weisgerber 1979). More detailed publications of this research were published between 1980 and 1988 (Gale et al. 1980; Wagner et al. 1980; Wagner and Weisgerber 1985, 1988).

During the fieldwork in the Aegean for the Oxford/ Heidelberg project, both Wagner and Gale independently became interested in collecting obsidian from such sources as Melos and Antiparos to explore new methods for its provenancing (Wagner et al. 1976; Gale 1981). The geographical range of the Oxford obsidian collection was greatly extended by samples kindly provided by A.C. Renfrew from his then unrivalled collection in Southampton. Renfrew suggested that beyond the initial joint project on silver sources for the Greek Archaic/Classical city states, there was an untapped potential field of research for the Isotrace Laboratory at Oxford into the sources of metals for the Bronze Age peoples of the Aegean and wider Mediterranean. This began in Oxford with studies of the sources of lead and silver for the Bronze Age Aegean (e.g., Gale 1980; Gale and Stos-Gale 1981a, b; Gale et al. 1984). As Rehren and Pernicka $(2008,238)$ have written "The breakthrough in provenancing by isotope ratios came with the extension of lead isotope analysis to copper and copperbased alloys (Gale and Stos-Gale 1982). By the combination of lead isotope ratios and trace element patterns it became possible, for the first time, to relate with high probability metal artefacts to specific ore deposits, some- thing that had been aimed at for more than 100 years. The work culminated with major syntheses for the metal from Cyprus by Stos-Gale et al. (1997) and for the south-east European Chalcolithic by Pernicka et al. (1997)" and one can add, by Gale et al. (2000). The Isotrace Laboratory was at first located at the University of Oxford in the Department of Earth Sciences, from 1989 in the Department of Nuclear Physics, and from 1994, it remained physically in Physics but was for administrative purposes part of the Research Laboratory of Archaeology.

Since the mid-1970s, all of the projects on lead isotope provenance studies at Oxford and Heidelberg have been based on parallel geological and archaeo-metallurgical collection of samples for analysis and mapping the ore deposits, ancient mines and slag heaps relevant to Bronze Age archaeology. The main interest of both teams was in the beginnings of metallurgy in the Mediterranean, South East and South West Europe, Anatolia and the Near East and resulted in many publications covering mineral deposits in Greece, Cyprus, Sardinia, Turkey, the Arabah Valley, Bulgaria, Italy and Spain.

\section{An overview of the development of methods for the measurement of lead isotope compositions}

It was clear from the beginning of the work at Oxford that it was necessary to achieve high accuracy ( $\pm 0.1 \%$ or better) and precision in the measurement of lead isotope ratios for metal provenancing. The classic method for the measurement of lead isotope ratios, developed largely for isotope geochemistry (Faure 1986), is thermal ionisation mass spectrometry with a magnetic sector mass spectrometer (TIMS). It was usual before, around 1974, to mount the sample as lead sulphide on a rhenium strip filament, which, on heating emitted ions into the mass spectrometer. This was a method which required microgramme amounts of sample and achieved only about $\pm 1 \%$ accuracy. In 1969 1973, Cameron et al. and Barnes et al. devised a thermal ionisation method based on the use of a silica gel/ phosphoric acid emitter on a rhenium filament which allowed the sample size to be reduced by an order of magnitude and the accuracy of lead isotope ratio measurement to be greater than $\pm 0.1 \%$ (Cameron et al. 1969; Barnes et al. 1973; Arden and Gale 1974). ${ }^{1}$ A great advance which allowed lead isotope analyses from different laboratories to be compared on the same absolute basis was the introduction by the US National Bureau of Standards of

\footnotetext{
${ }^{1}$ An improvement of the NBS silica gel/phosphoric acid emitter was later reported (Gerstenberger and Haase 1997) which allowed 10 nanogram amounts of $\mathrm{Pb}$ to be analysed by TIMS with an improved lead ion yield by a factor of 5 and the same accuracy.
} 
three isotope standards for lead (Catanzaro 1967a; Catanzaro et al. 1968). ${ }^{2}$ Since 1975 , the great majority of lead isotope analyses for metal provenancing purposes have been made with TIMS using essentially the methods of Barnes et al. (1973) and Arden and Gale (1974). A further very significant advance in sample throughput and accuracy of isotopic analyses using TIMS was the routine introduction of magnetic sector mass spectrometers using multi-collectors to collect all isotopes simultaneously in different collectors. The routine use of small samples necessitated also the development of low blank chemical separative methods carried out in special laboratories over-pressured by highly filtered air to reduce contamination to very low levels. The introduction of double-spike internal tracer [202 Pb-205 Pb] techniques, not available for routine measurements, allowed the reduction of absolute $2 \sigma$ errors to $\pm 0.002 \%$ for multicollector TIMS and the attainment of high accuracies for the measurement of the lead isotope compositions of the NBS/ NIST lead isotope standards (Todt et al. 1996).

A more recent development has been the introduction of an inductively coupled plasma source fitted to a magnetic sector multi-collector mass spectrometer (MC-ICPMS) for high precision isotopic analysis, amongst which was the application to lead isotope mass spectrometry (Hirata 1996; Rehkämper and Halliday 1998; Belshaw et al. 1998). Hirata has shown that this technique can attain a precision of lead isotope ratios of the order of $\pm 0.01 \%$ using nanogramme samples of lead in a comparatively rapid mass spectrometric procedure. This technique has, for example, been applied to study the possible variation of the isotope compositions of lead in cores taken from copper 'oxhide' ingots (Gale 2005) to central European copper artefacts (Niederschlag et al. 2003) and to demonstrate for the first time that the isotopic composition of copper (Gale et al. 1999) and of tin (Nowell et al. 2002) is variable in some ores and archaeological artefacts.

MC-ICPMS analyses are certainly the way ahead for lead isotope provenancing and other applications of isotope geochemistry to archaeology. However, the practical experience of one of the present authors in using this technique in the advanced Earth Science laboratories, Oxford, would suggest that Pollard and Heron (2008) were perhaps over optimistic when they wrote "...widespread use of highresolution ICP-MS machines could herald a new age of rapid and relatively cheap isotopic and chemical studies of archaeological material." The capital and running costs of an MC-ICPMS instrument are if anything more than for a

\footnotetext{
$\overline{2}$ The absolute isotope abundance ratios of these standards was first determined by a very accurate and precise triple filament TIMS technique (Catanzaro 1967b) which unfortunately requires large samples for analysis and is thus not suitable for routine use in isotope geochemistry.
}

TIMS machine, and many owners of such MC-ICPMS machines are unwilling to allow the direct introduction of directly dissolved samples into the ICP source (for good economic and analytical reasons), so that the timeconsuming step of chemical separation of the element to be analysed in an expensive low blank laboratory is usually still required. This is not only a question of practicality and economics but also because lack of chemical separation can expose one to problems arising from the fact that large amounts of matrix included with the sample may cause differential mass bias behaviour between samples and standards, as well as the possibility of introducing isobaric interferences (e.g. Rehkämper and Mezger 2000).

Care should be taken not to confuse MC-ICPMS with an ICP source fitted to a quadrupole mass spectrometer (ICPQMS) which, though very useful for the chemical analysis of samples taken from archaeological objects, does not possess the accuracy or precision needed for lead isotope analyses applied to archaeological provenancing studies and if misused for this purpose can lead to incorrect conclusions. Hirata (1996) has briefly discussed the severe restrictions of precision and accuracy of isotope ratio measurements made by ICP-QMS and gives references to work which has demonstrated this experimentally. Segal and Halicz (2005) have shown that lead isotope analyses by MC-ICPMS are an order of magnitude more accurate than those made by using ICP-QMS.

Pollard and Heron (2008) are perhaps also overoptimistic when they refer to the paper on the lead isotope analyses of Roman silver coins by Ponting et al. (2003) as "... a clear example of the way forward...". Ponting et al. used highresolution MC-ICPMS with sampling by laser ablation which in theory is very attractive, since it completely avoids any chemical separation. However, it is well known that there are often matrix effects to consider when using laser ablation (e.g. Rehkämper and Mezger 2000), and Ponting et al. (2003) did not investigate whether they were measuring correct lead isotope ratios when using laser ablation as the sampling method, for which they did not run an external standard. A hasty reading of their paper, and the good reproducibility for the lead isotope standard NBS981, superficially suggests that all is well, but a careful reading shows that they ran the standard in solution by injecting it directly into the plasma, with no involvement at all of laser ablation (Ponting et al. 2003). So their work did not at all test the accuracy of the laser ablation lead isotope analyses of the coins. A more professional investigation of matrix effects in laser ablation source MC-ICPMS was given by Baker et al. (2006), who took care to include an external standard glass (NIST610) for normalisation of the laser ablation isotopic analyses. They made new MC-ICPMS lead isotope analyses of archaeological silver and copper artefacts both by bulk solution (no chemical separation) and 
by laser ablation of solid samples using MC-ICPMS, comparing the data with previous TIMS analyses of the same samples by the Isotrace Laboratory, University of Oxford. Baker et al. (2006) reported that comparison of TIMS and MC-ICPMS solution results with laser ablation MC-ICPMS data on the same samples is variable. For relatively high-lead samples ( $>500 \mathrm{ppm})$, there is excellent agreement between in situ data and previous TIMS results. However, for lower-lead samples $(<100 \mathrm{ppm})$, the laser ablation data are considerably offset from TIMS and bulk dissolution analyses, consistent with an inaccurate correction for instrumental mass bias when using the NIST610 glass as an external standard. The authors suggest that this is probably an effect of relatively high matrix to lead ratios which vary space-charge effects in the plasma. The contrasting accuracy between the high-lead silver and copper samples and the relatively low-lead Uluburun copper ingot samples suggests that the laser ablation method (using NIST610 glass as an external standard to monitor instrumental mass bias) is suitable for metals containing high concentrations of lead but must be used with care for lower-lead metals.

\section{Possible fractionation of lead isotopes during ancient metallurgical processes}

Lead isotope provenancing would fall at the first hurdle should fractionation of lead isotopes occur during ancient metallurgical processes, i.e. if the lead isotope composition in the metal extracted from a metal ore should happen to be different from the lead isotope composition in the metal ore due to fractionation in smelting, refining, working, casting, cupellation or corrosion processes.

In other words, it is necessary that whether the lead occurs as a major element in the antiquity (lead metal, lead pigments, lead bronzes) or as a minor element (e.g. copper, iron, silver, or zinc artefacts, unleaded glasses, glazes), the isotopic composition of that lead will be the same as the isotopic composition of the lead in the ore deposit from which it derives. This was called into question by Budd et al. (1995a) and Pollard and Heron (2008), who hypothesised that changes in lead isotope composition due to nonequilibrium evaporation during smelting, for example, could produce changes in lead isotope composition great enough to move the isotopic composition in the smelted metal quite outside the field of isotopic composition of the ores being smelted (Pollard and Heron 2008, Fig. 9.6). Their hypothetical calculations of fractionation relied on a thermodynamic model (Mulliken and Harkins 1922) designed to describe evaporation in a vacuum from a liquid (mercury) where the vapour phase was efficiently removed from the system by condensation on a cold surface. From its inception by Pollard, it seemed inappropriate to apply this model to ancient processes such as smelting, fire refining and cupellation, and so it has proved from the experimental investigation of such processes. Moreover Macfarlane (1999), applying a somewhat more realistic theoretical model of the smelting process, deduces that evaporation of lead during the smelting process is unlikely to fractionate the lead isotope composition of smelted metal away from the isotopic composition of the lead in the ore from which it was smelted.

Some direct evidence about possible lead isotope fractionation in metallurgical processes had in fact long been available. Experiments by Barnes et al. (1978) had given empirical proof that in a particular case, anthropogenic processes produced no measurable change in lead isotope composition. They heated a large sample of galena with charcoal in a closed crucible at $900^{\circ} \mathrm{C}$ for $18 \mathrm{~h}$ and then reduced it to lead at $900^{\circ} \mathrm{C}$ in $3 \mathrm{~h}$ in the presence of a weak air blast. Part of this lead metal was reserved for analysis; the remainder was oxidised at $900^{\circ} \mathrm{C}$ in $1 \mathrm{~h}$ to litharge in a stronger air blast. Some of this litharge was used to make a potassium lead silicate clear glass at $1,450^{\circ} \mathrm{C}$, while some of the litharge was used to make a yellow lead antimonate pigment at $950^{\circ} \mathrm{C}$. The lead isotope ratios of the four products were found to be the same as that of the galena to well within the quoted experimental error of $\pm 0.05 \%$; thus, no isotopic fractionation of lead was observed in these experiments. There is no doubt that the accuracy of the lead isotope analyses of the products of these procedures was as good as modern analyses. Barnes et al. (1978) clearly state that they used TIMS with the then new silica gel/phosphoric acid activation method which they had themselves developed and which they fully describe and evaluate in Barnes et al. (1973), a technique whose accuracy was subsequently fully confirmed by such authors as Arden and Gale (1974).

Thus, the work of Barnes et al. (1978) is analytically beyond reproach. However, Pollard and Heron (2008) were correct to observe that the loss of lead in the experiments of Barnes et al. (1978) did not exceed circa 5\%, so that it had not been established that isotopic fractionation of lead might not occur in procedures where the loss of lead was large. Preliminary confirmation that lead is not measurably fractionated by smelting or cupellation involving larger losses of lead came from our own previously unpublished work in 1983 with U. Zwicker. As shown in Table 1, the lead isotope compositions of argentiferous lead metal smelted by Zwicker in Erlangen from a lead-silver ore from the Rammelsberg mine (Harz) and of litharge resulting from the cupellation of that argentiferous lead are identical to the lead isotope composition of the ore within the error of $\pm 0.1 \%$ established for our lead isotope ratio measurements (made in the Isotrace Laboratory, 
Table 1 Comparison of lead isotope compositions, measured in Oxford, of galena, lead and litharge

\begin{tabular}{lccc}
\hline Sample & ${ }^{208} \mathrm{~Pb} /{ }^{206} \mathrm{~Pb}$ & ${ }^{207} \mathrm{~Pb} /{ }^{206} \mathrm{~Pb}$ & ${ }^{206} \mathrm{~Pb} /{ }^{204} \mathrm{~Pb}$ \\
\hline Argentiferous galena, Rammelsberg: 61 E & 2.08933 & 0.85586 & 18.220 \\
Lead metal smelted from ore 61E & 2.09097 & 0.85610 & 18.233 \\
Litharge from cupelling the smelted lead metal & 2.08937 & 0.85648 & 18.213 \\
\hline
\end{tabular}

Oxford, using TIMS with the silica gel/phosphoric acid emitter method on rhenium filaments).

Later, direct experiments by Pernicka and Bachmann (1983), with lead isotope analyses carried out by Todt, were reported not to have shown any measurable change of lead isotopic composition in silver cupelled from argentiferous lead metal that had been smelted from galena from Lavrion; unfortunately, they did not give any actual lead isotope data to substantiate their claim. A series of metallurgical processes on galenas and lead carried out in Bradford (Budd et al. 1995b) was also claimed to show no measurable change in lead isotope compositions, though again no numerical isotopic data were reported so that this work cannot be used either to prove or disprove fractionation, as noted by Tite (1996). Pollard and Heron (2008) also write about these lead metallurgical procedures carried out in Bradford stating that "isotopic measurements showed no significant change in the isotopic ratios (McGill et al. 1999)", but again no lead isotope data are published either by Pollard and Heron (2008) or by McGill et al. 1999, so again nothing is proved.

Since knowledge of the exact details of metallurgical processes practised in ancient times remains scarce and modern simulations are thus uncertain, it seems clear that the most rigorous tests of possible lead isotope fractionation should involve the actual remains of ancient metallurgical processes. To this end, isotopic analyses were made in the Oxford Isotrace Laboratory of the traces of lead (from $0.5 \%$ to a maximum of $3 \% \mathrm{~Pb}$ ) in a series of Archaic and Classical Athenian silver tetradrachms together with argentiferous galena ores from the Lavrion mines (Marinos and Petrascheck 1956) in Attica, south of Athens in Greece. Athenian tetradrachms, the 'owl' coinage of the Archaic and Classical city state of Athens, are silver coins of mass about $17.15 \mathrm{~g}$ bearing on the obverse the helmeted head of Athena and on the reverse an owl standing; in the field, an olive branch and $A \Theta E$, all in an incuse square (see Kraay 1976). This Athenian silver coinage was the most copious of the time, having a wide distribution all over the Greek world and beyond. Contemporary written sources make it quite clear that this coinage was made from silver obtained from the argentiferous lead ores at Lavrion (see references in Kraay 1976; Seltman 1977 and in Fischer-Bossert 2008). It began to be minted around 525B.C. For the present purpose, we are safe in including in our analytical programme tetradrachms minted up to about 450-446B.C., when the Athenian currency decree was announced, amongst the provisions of which were measures for the collection of foreign silver and for its conversion into Athenian coin (Kraay 1976).

The Athenian silver tetradrachms analysed in Oxford form a particularly rigorous test of the possibility that lead isotope fractionation may have occurred in ancient metallurgical processes. They were certainly made (between 525 and 450B.C.) from silver that had been obtained from Lavrion argentiferous lead ores, first by smelting to produce argentiferous lead and then by cupelling this silver-rich lead to produce the silver. Moreover, the study by Conophagos (1980) of the remains of these ancient processes in Lavrion argues persuasively that two successive cupellation stages, in two different cupellation furnaces, were used (in both of which lead losses might have occurred) and suggests that a yet final stage of fire refinement then followed until the silver was so pure as to exhibit the phenomenon of 'rochage' on cooling. Moreover, the trace element analyses of Athenian silver tetradrachms, together with a detailed experimental geochemical study of the cupellation process made by Pernicka and Bachmann (1983), led them to conclude that a final silver refining process (following cupellation) was used by the Athenians. Consequently, these silver tetradrachms appear to have been made of silver which was produced by two successive cupellations of argentiferous lead smelted from argentiferous Lavrion lead ores, with a final stage of refinement of the silver. In each of these processes, some lead will have been lost, with the possible fractionation of the isotope composition of the traces of lead in the final silver away from the isotopic composition of lead in the Lavrion lead ores.

The range of lead isotope compositions for the argentiferous lead ores at Lavrion is currently established by thermal ionisation mass spectrometry of 112 ores from different parts of the deposit. Of the ore data used, 17 ores were published by Barnes et al. (1974); these ores were from the regions of Plaka, Kamareza and Esperance in Lavrion. For the more recent analyses in Oxford a modified VG Isotech Isolab54, three-stage E-B-E, fully computercontrolled, mass spectrometer was used, with samples of highly purified lead of about $200 \mathrm{ng}$ being loaded with the usual silica-gel/phosphoric acid activator onto rhenium filaments. All measurements reported here for silver Athenian coins were made using four of the seven Faraday collectors in this spectrometer to collect simultaneously the 
isotopes ${ }^{204} \mathrm{~Pb},{ }^{206} \mathrm{~Pb},{ }^{207} \mathrm{~Pb}$ and ${ }^{208} \mathrm{~Pb}$ in static multicollector mode. All isotope data were put on an absolute basis by reference to many repeat measurements for the lead isotope standard SRM981 issued by the US National Institute of Standards and Technology (NIST, formerly NBS). The absolute isotope ratio data used for SRM 981 was that reported by Todt et al. (1996).

Lead isotope analyses have also been made in the same way for 22 Athenian silver tetradrachms and one Athenian Wappenmünzen (an obol, for which the numismatic evidence is that it also was made from Lavrion silver: $M$. Price, private communication; unlike the Wappenmünzen didrachms, which are associated with Pisistratus and his silver mines in Thrace (Kraay 1976)). These lead isotope data are given in Table 2. Previous less accurate analyses for some of these coins were published in Gale et al. 1980 or in Gale and Stos-Gale 1996. All data used in the present paper are either for coins not previously analysed or have been reanalysed for the present paper using the new mass spectrometer mentioned above. These analyses are plotted in Fig. 1 in relation to lead isotope data for the Lavrion ores. The lead isotope data for six didrachm Wappenmünzen published previously (Gale et al. 1980) fall outside the Lavrion field, in accordance with the numismatic and historical evidence that places these issues before the owl coinage and disassociates them from the Lavrion mines. A coin from the Asyut Hoard (Price and Waggoner 1975: no. 65) published (Gale et al. 1980) as being an Athenian tetradrachm, and having a distinctly non-Lavrion lead isotope composition, was mistakenly attributed to Athens; its photograph in the photographic inventory of the MaxPlanck-Institut für Kernphysik, Heidelberg, of which a duplicate is held in Oxford, shows it certainly to be an issue of the Orrescii.

The conclusion from Fig. 1 is that the lead isotope analyses for the tetradrachms all fall within the data for the Lavrion ores; there certainly are no large-scale fractionations of the isotope ratios away from those characteristic of the argentiferous lead ores from which the ancient authors show that they were made. Consequently, these data support the idea that there is no measurable fractionation of lead isotopes through the smelting, two separate
Table 2 Measured lead isotope ratios for some Archaic and Classical Athenian silver coins

Coins marked (A) are from the Asyut Hoard and are pre- $475 \mathrm{BC}$

\begin{tabular}{|c|c|c|c|c|}
\hline No & Coin & ${ }^{208} \mathrm{~Pb} /{ }^{206} \mathrm{~Pb}$ & ${ }^{207} \mathrm{~Pb} /{ }^{206} \mathrm{~Pb}$ & ${ }^{206} \mathrm{~Pb} /{ }^{204} \mathrm{~Pb}$ \\
\hline 1 & Wappemunzen Obol-Wheel & 2.05691 & 0.83129 & 18.861 \\
\hline 2 & 14 Tetradrachm 4th C BC & 2.05960 & 0.83220 & 18.851 \\
\hline 3 & 17 Tetradrachm $450 \mathrm{BC}$ & 2.06110 & 0.83230 & 18.872 \\
\hline 4 & 19 Tetradrachm 4th C BC & 2.06195 & 0.83239 & 18.859 \\
\hline 5 & 31 Tetradrachm (A) & 2.05923 & 0.83133 & 18.855 \\
\hline 6 & 32B Tetradrachm (A) & 2.05770 & 0.83128 & 18.851 \\
\hline 7 & 33B Tetradrachm (A) & 2.05730 & 0.83116 & 18.841 \\
\hline 8 & 34 Tetradrachm (A) & 2.06116 & 0.83198 & 18.902 \\
\hline 9 & 35B Tetradrachm (A) & 2.05832 & 0.83148 & 18.853 \\
\hline 10 & 36 Tetradrachm (A) & 2.06120 & 0.83186 & 18.850 \\
\hline 11 & 37 Tetradrachm (A) & 2.05772 & 0.83126 & 18.852 \\
\hline 12 & 39 Tetradrachm (A) & 2.06206 & 0.83154 & 18.878 \\
\hline 13 & 40 Tetradrachm (A) & 2.05871 & 0.83120 & 18.858 \\
\hline 14 & 63 Tetradrachm (A) & 2.05863 & 0.83157 & 18.833 \\
\hline 15 & KIM (2) Tetradrachm $450 \mathrm{BC}$ & 2.06297 & 0.83231 & 18.869 \\
\hline 16 & KIM (4) Tetradrachm $450 \mathrm{BC}$ & 2.06230 & 0.83247 & 18.835 \\
\hline 17 & KIM (3) Tetradrachm $450 \mathrm{BC}$ & 2.06154 & 0.83229 & 18.838 \\
\hline 18 & 21 Tetradrachm $450 \mathrm{BC}$ & 2.06249 & 0.83252 & 18.850 \\
\hline 19 & PARIS 8 Tetradrachm & 2.06175 & 0.83264 & 18.833 \\
\hline 20 & KIM (1) Tetradrachm $450 \mathrm{BC}$ & 2.06275 & 0.83239 & 18.857 \\
\hline 21 & PARIS 323 Tetradrachm & 2.05749 & 0.83186 & 18.777 \\
\hline 22 & 41 Tetradrachm (A) & 2.06024 & 0.83191 & 18.858 \\
\hline 23 & 38 Tetradrachm (A) & 2.05974 & 0.83247 & 18.829 \\
\hline 24 & AA (Turkish hoard) $\sim 450 \mathrm{BC}$ & 2.06029 & 0.83234 & 18.812 \\
\hline 25 & $\mathrm{BB}$ (Turkish hoard) $\sim 450 \mathrm{BC}$ & 2.05969 & 0.83183 & 18.834 \\
\hline 26 & $\mathrm{CC}$ (Turkish hoard) $\sim 450 \mathrm{BC}$ & 2.06014 & 0.83224 & 18.818 \\
\hline 27 & DD (Turkish hoard) $\sim 450 \mathrm{BC}$ & 2.05912 & 0.83094 & 18.847 \\
\hline
\end{tabular}



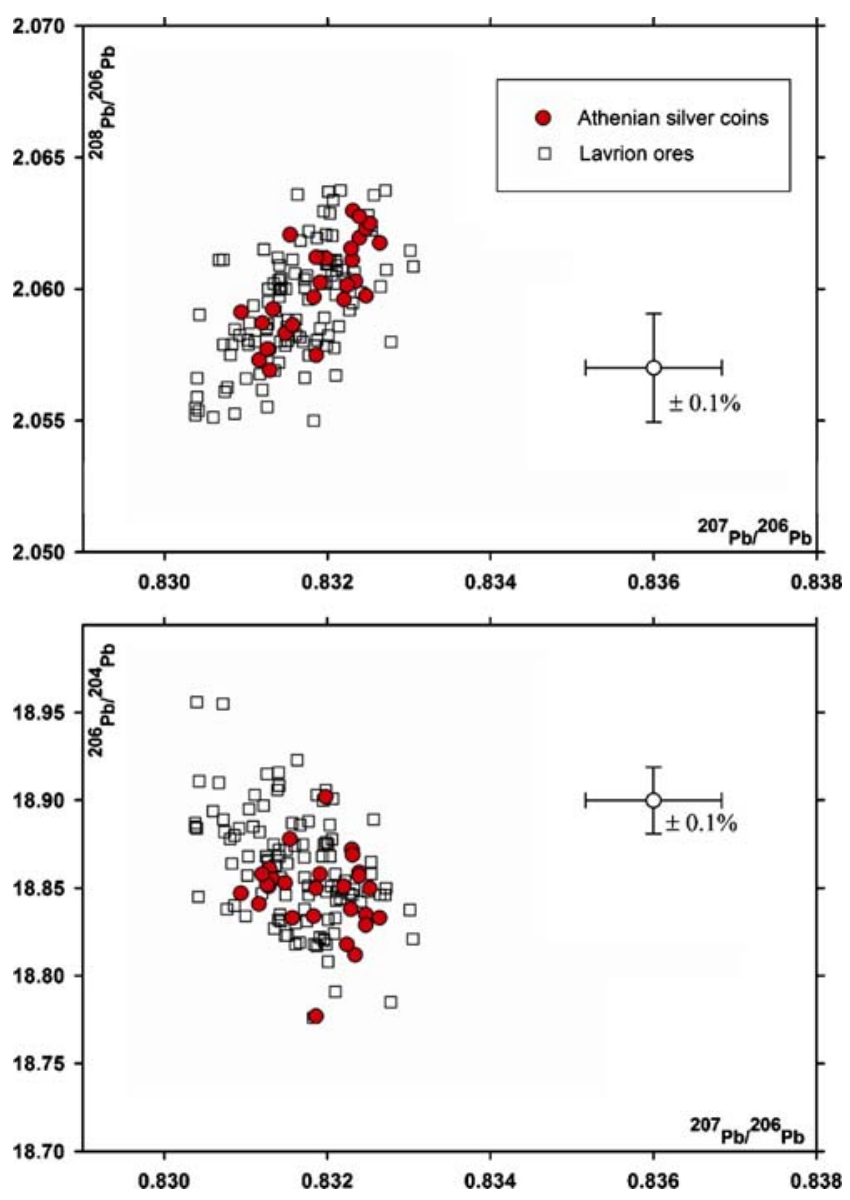

Fig. 1 Lead isotope data for 27 Archaic and Classical Athenian silver coins compared with data for $\approx 100$ ores from the Lavrion ore deposit in Attica. It is clear that the lead isotope data for the silver coins, which were produced from Lavrion lead/silver ores by smelting, cupellation and refining steps, match the isotopic data for the ores and are not fractionated from them by smelting, cupellation or refining processes

cupellations, and one silver refining step which intervened between the original Lavrion argentiferous lead ores and the final minting of the Athenian silver coins.

Further recent analyses of ancient lead and copper slags, lead and silver metal, and litharge prove that in spite of possible substantial losses of lead, the processes of smelting of copper, fire refining, and the cupellation of silver do not affect the lead isotope compositions of the obtained metals (Gale and Stos-Gale 1996, 2000; Stos-Gale et al. 1998a, b, and references therein). All experimental work so far shows that no measurable changes are detected between the lead isotope compositions of the components in the chain: oreslag-metal and ore-lead metal-litharge-silver. We conclude that there is now overwhelming evidence that anthropogenic metallurgical processes do not measurably alter the isotopic composition of lead and that the suggestions of Budd et al. (1995a) to the contrary are incorrect. This question is discussed at greater length by Gale and Stos-Gale (1996, 2000).
Based on the same inappropriate theoretical framework (Mulliken and Harkins 1922), Budd et al. (1995c) and Pollard and Heron (2008) suggested that there should be relatively large alterations in the isotopic composition of tin produced by extractive metallurgical processes. In fact, Gale (1997), Yi et al. (1999), and Begemann et al. (1999) have, by direct measurement, shown that such anthropogenic alterations of the isotopic composition of tin metal do not occur at the level predicted by Budd et al. (1995c). On the other hand, Nowell et al. (2002) have demonstrated that there are variations of the isotopic composition of tin in naturally occurring cassiterite tin ores.

There also exists direct experimental confirmation that the weathering of glasses over periods of up to 2,600 years does not result in altered lead isotope compositions in the weathering product when compared with fresh interior glass (Brill 1969). Our own observations show that the lead isotope composition of the thick corrosion product on the exterior of two Early Cycladic lead boat models from Naxos, dating from about 4,800 years ago, is the same as the isotopic composition of the interior uncorroded lead metal (Gale and Stos-Gale 2000). Similar results have been obtained by Snoek et al. (1999) in comparing the lead isotope compositions of corrosion products with the uncorroded metal from which they were formed.

Though corrosion does not alter lead isotope compositions by fractionation, corroded samples of copper objects of low lead content can be problematic for lead isotope analysis. Corrosion affords the possibility of alteration of the true lead isotope composition of an artefact by exchange of lead, of differing isotopic composition, from the burial environment (Gale and Stos-Gale 2000). Snoek et al. (1999) have published similar caveats.

\section{Ore deposits: homogeneity of lead isotope composition}

In the formation of the majority of metal ore deposits, which are uranium-poor, the lead contained in those ore deposits is separated from the parent uranium and thorium. The "frozen-in" isotopic composition of the lead thus separated depends on the geochemical history of the source materials, specifically on the $\mathrm{U} / \mathrm{Pb}$ and $\mathrm{Th} / \mathrm{Pb}$ ratios and the timing of any variations in these ratios, including the time of final separation of the lead (see Gale and Stos-Gale 2000). As Barnes (1979) has remarked, it is theoretically possible for each ore deposit in the world to have its own unique isotopic composition, though in many cases, the differences between deposits may be so small as to demand the utmost precision and accuracy in analytical techniques in order to differentiate them.

It has sometimes been questioned by archaeometrists whether the isotopic composition of lead in an ore deposit 
is uniform throughout. Some have suggested that it is mainly the geologically conformable massive sulphide deposits which exhibit isotopic homogeneity, but this is not so. Gulson (1986) records that lead isotope homogeneity is exhibited also, for example, by such diverse ore deposits as carbonate-hosted deposits and vein deposits and discusses the underlying reasons for isotopic homogeneity in an ore deposit. Doubt has also been expressed whether the lead in different minerals from the same ore deposit, especially from the primary sulphides as opposed to oxidised minerals, will have the same isotopic composition. An investigation by Barnes et al. (1974) of the Lavrion ore deposit shows that, for the 17 ore samples analysed, the complete range of variation in lead isotopic composition is $0.28 \%$, and the isotopic composition is not correlated with geographical position or depth in the ore body, nor with ore type. Further work that confirms these conclusions for the Lavrion ore deposit, including the homogeneity of the isotopic composition of lead in galena and cerussite ores together with oxidised copper ores, has been reported by Stos-Gale et al. (1986, 1996).

A number of similar investigations have been carried out by other isotope geochemists. In one example for two deposits in Australia, Gulson and Mizon (1979) have shown that the complete range of lead isotope compositions in the primary sulphide ores is less than $0.3 \%$ and that the oxidised ores in the overlying gossan have lead isotope compositions indistinguishable from the deep primary sulphide ores. Many further examples are given by Gulson (1986) in the course of illustrating the value of lead isotope data in mineral exploration. The many copper ore deposits in Cyprus (Stos-Gale et al. 1997; Gale et al. 1997) if lumped together cover a relatively wide range of lead isotope compositions, but individual mines have a relatively small range of isotopic compositions.

There is of course an important caveat in that although the majority of $\mathrm{Pb}, \mathrm{Ag}$ or $\mathrm{Cu}$ deposits around the Mediterranean are indeed uranium-poor relative to the lead content, there do exist other ore deposits where present-day $\mathrm{U}, \mathrm{Th} / \mathrm{Pb}$ ratios are high and variable, which leads to a wide range of lead isotope compositions for different ore samples within the same deposit. Examples are Timna in Israel (Gale et al. 1990) and Feinan in Jordan (Hauptmann et al. 1992; Hauptmann 2007). These relatively rare situations make lead isotope provenancing in those regions more difficult, but useful conclusions have still been made from lead isotope analyses of artefacts from EBA sites in the Palestine region in relation to the copper deposits in Feinan and Timna (Hauptmann 2007).

A misunderstanding exists in the archaeometric literature (Pollard and Heron 2008; Hauptmann 2007) about what is referred to as the large spread of lead isotope compositions for the "ore deposit of the Mississippi valley". First, the
Upper Mississippi Valley (UMV) is not a single ore deposit, but a huge ore district of over $10,000 \mathrm{~km}^{2}$, containing many individual ore deposits which individually have relatively uniform lead isotope compositions-this is reviewed in Gale (1989) and in Gale and Stos-Gale (2000). For example, the Amelia mine within the UMV district shows a variation in lead isotope composition of only about $0.25 \%$ (Gale and Stos-Gale 2000). It is true that a single large galena crystal from the Buick mine in this ore district has been shown by Hart et al. (1981) to show a total variation of about $4 \%$ in lead isotope ratios, but such variations would be averaged out amongst the many galena samples that would constitute the smelting charge of a furnace. Isotopic heterogeneities across a large ore district do not necessarily preclude lead isotope compositions from pinpointing the source of a metal artefact to an individual ore deposit within that district. For example, Farquhar and Fletcher (1980, 1984), Farquhar et al. (1995) have successfully provenanced artefacts to UMV ore deposits in a number of studies. To use the UMV as a model for Mediterranean ore bodies would be a false comparison.

The extension of the concept of a lead isotope field for a single ore deposit to cover an island or a geographical region is fraught with difficulties, as is clearly illustrated by the examples of Cyprus and Sardinia (Stos-Gale et al. 1997; Gale 1999; Baxter 2003). It is the precise coincidence of lead isotope compositions of particular artefacts with particular ore deposits that is required before it can be concluded that the metal of the artefact most probably came from the named ore deposit. If some ore deposits have overlapping lead isotope compositions, then the conclusions for artefacts plotting in such regions must necessarily be less well defined. It is largely a question of semantics to engage in arguments that lead isotope analyses can only exclude ore sources and can at best establish only that an ore deposit is consistent with being the metal source for particular artefacts. If a set of copper artefacts have lead isotope compositions matching only one copper ore deposit, among the set of copper ore deposits that it is geographically/archaeologically reasonable to consider, the normal application of scientific method would lead to the conclusion that, given the present state of knowledge, those artefacts were made of copper from that deposit. Naturally, such conclusions must be based on a comprehensive lead isotope investigation of all appropriate ore deposits.

\section{The interpretation of lead isotope analyses for provenance studies}

From the very beginning, at Oxford, the interpretation of the data for provenance studies in archaeology was based on comparison of the three lead isotope ratios in two 
'mirror' plots: where the horizontal axis was always ${ }^{207} \mathrm{~Pb} /{ }^{206} \mathrm{~Pb}$ and the two vertical ones ${ }^{208} \mathrm{~Pb} /{ }^{206}$ and ${ }^{206} \mathrm{~Pb} /{ }^{204} \mathrm{~Pb}$, as plotted on Fig. 1. The choice of these particular three independent ratios was partly derived from the method of representation of lead isotope measurements in isotope geology (see Gulson 1986), partly for convenience, because these three ratios always differ by one order of magnitude (e.g. 0.8.., 2.07.., 18.8...) and, therefore, are easy to distinguish and remember. For roughly the first 10 years, the data were plotted by hand, but the use of the graph plotting software SIGMAPLOTC in the mid-1990s revolutionised the possibilities of quick comparisons of a large number of data. In the first decade we were trying to ease the task of comparisons by plotting the ore data as 'fields' enclosed by ellipses, followed by the use of stepwise discriminant analysis (for examples, see Gale and Stos-Gale 1992).

It is not an easy matter to establish the boundaries of the range of lead isotope compositions for particular ore deposits. Ideally, it requires analyses of about 30 to 50 different ore samples from a particular ore deposit to establish its characteristic lead isotope field (the question of sample size is discussed by Baxter (2003) and Baxter et al. (2000)). Early works by Brill and Wampler (1965, 1967) seem not to have appreciated these problems; for example, they identified a so-called Group L of lead isotope compositions that they associated loosely with the Lavrion ore deposit in Attica. Later work in Washington and Oxford showed that the true Lavrion ore deposit exhibited a much more restricted range of lead isotope compositions (for a comparison between Brill's Group L and the true Lavrion field see Gale, Fig. 8 (1980)), so that conclusions based on the original Group L will have been in error.

Later interpretation of lead isotope analyses for provenancing purposes has a strange history which resulted in a fierce, but largely sterile, controversy when a paper using multivariate statistics by Sayre et al. (1992) came under attack in the pages of Archaeometry and the Journal of Mediterranean Archaeology, particularly by Budd and Pollard. Curiously, this was not the first paper to attempt to use multivariate statistics for the interpretation of lead isotope analyses in archaeology; those were in fact papers by McGeehan-Liritzis and Pollard (1986) and Pollard and Gale (1986; quoted by Budd et al. 1993). It was in fact Pollard himself who first introduced multivariate statistical interpretation into lead isotope provenance work (see Fig. 13 in Gale 1989, and see the remarks of Cherry and Knapp 1991 on this subject). Initially, a main problem encountered when attempting to use multivariate statistics for the interpretation of lead isotope data was the rather small number of data points available for most of the ore deposits. Therefore, in the early 1990s, when we started using the new multi-collector mass spectrometer, much effort in the Isotrace Laboratory was directed towards analysing many ores and slags from the same location.

Later the Isotrace Laboratory began to use trivariate discriminant statistical analysis, an example being the paper by Gale (1991). In fact, the Isotrace Laboratory had inadvertently used multivariate statistics in an elementary way from early 1988 . For some time, we had attempted to guide the eye in lead isotope diagrams, by enclosing groups of lead isotope data for ores by rather arbitrary hand drawn closed curves (e.g. Gale et al. 1984). In 1988, Gulson kindly provided us with the algorithm (devised by R.L. Sandland) to construct the enclosing 95\% confidence ellipses which he used in his book on lead isotope mineral exploration (Gulson 1986), which we thereafter used as a convenient method to construct bounding ellipses surrounding ore data in graphical plots of lead isotope data (e.g. Gale 1998). Since the numerical value of the confidence level for these ellipses depends on the multivariate normality of the data it surrounds, it will not be correct for lead isotope data, which is not normally distributed (Baxter and Gale 1998; Baxter 1999). Such ellipses can still be useful, however, to guide the eye for complex lead isotope diagrams. Before considering further the statistical or graphical interpretation of lead isotope provenancing, we should again emphasise a fundamental point, which will seem obvious to most but which nevertheless has sometimes been overlooked: the lead isotope analyses of artefacts made of a particular metal should be compared only with isotopic analyses of ores which contain that metal (e.g. the lead isotope composition of a silver object should be compared only with that for ores containing silver).

Before, about 1990, trivariate statistical analysis of lead isotope data had rarely been used, save for the pioneering work by Pollard referenced above. The majority of papers made use of the two graphical presentations possible of the three measured lead isotope ratios. Since 1993, only Sayre et al. (2001) have continued to use multivariate statistical methods in comparing lead isotope data for ores and artefacts, since most have accepted that doubt has been cast on the normality assumption and hence on those procedures that use this assumption. The Bradford group (Scaife et al. 1999) and Baxter et al. (2000) have experimented with the use of kernel density estimation (KDE) to represent lead isotope fields for ores, but to our knowledge, this method has not as yet been applied to comparisons of isotopic data for artefacts and ores. Baxter (2003) discusses the technical difficulties (data smoothing, etc.) with using $\mathrm{KDE}$, and other statistical issues of lead isotope provenancing. Baxter (2003) clearly writes that in general, graphical analysis of comparative lead isotope data seems preferable as it is less dependent on assumptions that prejudge the shape of a field and about what constitutes an 
outlier. Baxter's reservations throw doubt on the view (Pollard and Heron 2008) that KDE techniques offer a positive and more reliable way forward for the interpretation of lead isotope data in the future. It should be pointed out that Pollard commits a major error in referring to KDE work (Pollard and Heron 2008) when he writes, in relation to his Fig. 9.12 which gives a KDE representation of the ore data for Cyprus:

Shown for comparison on this figure is the original 'Oxford ellipse' previously derived from the same data. The KDE model appears to be a much better representation of the original data than the imposed ellipse, and suggests that use of this ellipse might underestimate the true extent of the ore field, and hence lead to misclassification of the source of ancient artefacts.

But the KDE representation given in Pollard's Fig. 9.12 is based on all the Cypriot ore deposit data (more than 200 data) which Oxford published in 1997, whilst Pollard's superimposed 'Oxford ellipse' is based only on approximately 43 data points published up to 1997. This is an incorrect comparison. If an ellipse is correctly constructed using all the 1997 data, as shown by the black ellipse in Fig. 2 of the present paper, it encloses the whole of the KDE representation, the alleged discrepancy disappears, and Pollard's misleading argument collapses. Of course, this black ellipse should not be used to define an overall "Cypriot field", because the ellipse clearly encloses isotopic space not occupied by any lead isotope data for Cypriot ores (for ease of comparison, the blue ellipse on Fig. 2 is that based on the 43 data points for Cypriot ores published up to 1997.)

It should also be pointed out that Stos-Gale et al. (1997) explained in 1997 and later papers (Gale 1999) that we no longer used multivariate statistics and had reverted to the simple two bivariate plots and point-by-point comparisons of LIA for artefacts and ores as illustrated in Fig. 1 of this paper (as is also the practice of Begemann, Hauptmann, Pernicka, Schmitt-Strecker and other authors such as Pinarelli (2004) and Valera et al. (2002)).

One further point is that lead isotope provenancing today often requires the comparison of data for large numbers of artefacts with data for large numbers of ores. We agree with Baxter (2003) that it would be useful to use an initial screening device to identify uncertain cases that could then be subjected to more detailed graphical scrutiny, using point-by point comparisons between isotopic data for ores and artefacts, as illustrated above in Fig. 1. For this initial screening, we use an algorithm which computes the Euclidean distances (Baxter 2003) between the lead isotope data for an artefact with the whole isotopic database for ores containing the metal of which the artefact is made. Currently, our procedure for interpreting the lead isotope data for ancient artefacts is as follows:

1. Euclidean distances are calculated between the lead isotope (LI) ratios of each artefact and all relevant and currently available lead isotope data points for ore and slag samples. The comparisons are made using simple software (TestEuclid) that calculates the

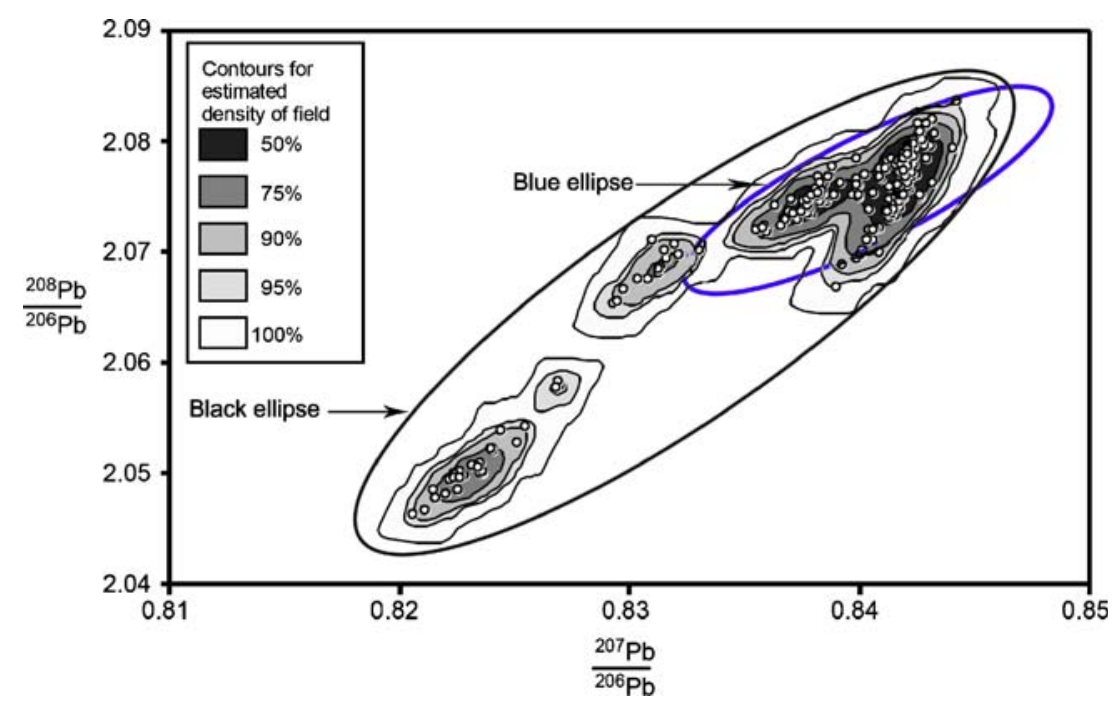

Fig. $2 \mathrm{KDE}$ of the Troodos ore deposits on Cyprus (constructed from the data published by Gale et al. 1997). The black ellipse shown embraces all of the 1997 data $(\approx 240$ data) but should not be used to define an overall "Cypriot field", because the ellipse clearly encloses isotopic space not occupied by any lead isotope data for Cypriot ores. In Fig. 9.12 of Pollard and Heron (2008), a smaller ellipse is drawn around only the $\approx 43$ Cypriot ore data published prior to Gale et al.
1997 and is incorrectly compared with the KDE representation based on $\approx 240$ data (for clarification, the smaller blue ellipse shown here is that erroneously used by Pollard and Heron to compare with the KDE representation for the totality of published lead isotope data for Cypriot ores). Baxter (2003) has discussed the technical difficulties standing in the way of using KDE for the interpretation of lead isotope analyses. This is based on Scaife et al. (1999) 
Euclidian distance (TED) between the points in threedimensional space defined by the three independent lead isotope ratios. The overall accuracy of the TIMS lead isotope analyses is $\pm 0.1 \%$ for each of the three LI ratios; the TED is expressed as the fraction of this error. That means that two points at $T E D=1$ are identical within one analytical error; therefore, the metal and the ore/slag can, in principle, have the same geological origin.

2. The second stage of interpretation of the data must include the comparison of data on two two-dimensional plots of LI ratios to assess the patterns of distribution of all ore data points for each of the deposits in relation to the data points representing the artefacts.

3. Finally, the geochemistry and history of exploitation of the ore deposits identified as possible sources has to be evaluated.

In the great majority of cases at the end of these procedures, all but one ore source can be eliminated. Finally, the possibility of the metal originating from a mixture of ores (or metals) from more than one source is evaluated.

\section{The Oxford scientific research and survey plan (1978-2001)}

At a conference in the late 1970s, and in Southampton, Professor Colin Renfrew suggested to Noel Gale that it would be interesting to apply lead isotope studies to the earliest Aegean metallurgy to test the old theories of the 'diffusion' of metallurgy from the Near and Middle East to Europe and generally to identify the sources of the earliest metals and the Bronze Age metal trade routes. Following this conversation, in 1979, the authors of this paper started a project funded by the UK Science and Engineering Research Council on the Bronze Age sources of lead and silver in the Mediterranean. The scientific plan for this project included a survey of lead-silver mines and sampling of lead and silver artefacts from Bronze Age sites excavated in Greece. The comparison of lead isotope compositions of ores and slags with those of the artefacts was to give the answer to the origin of the metals (Gale and Stos-Gale 1981a, b; Gale et al. 1984) and to provide the first objective proof that Lavrion in Attica was an important Bronze Age source of lead and silver. A few years later, the team from Heidelberg-Mainz started surveys of the mineral deposits of Turkey which provided some essential lead isotope data for comparisons in our research (Pernicka et al. 1984; Wagner et al. 1986).

In 1982, the first results of lead isotope analysis of copper-based artefacts were published (Gale and Stos-Gale
1982). By that time, we had already started a wide ranging collaboration with the Greek Geological Service (Institute of Geology and Mineral Exploration (IGME)) and Aegean archaeologists from Europe and the USA. Through membership in the British School of Archaeology at Athens and frequent participation in archaeological conferences, we were identifying specific archaeological questions that could be tackled by chemical and lead isotope analyses of excavated Bronze Age metals and forming contacts with the archaeologists excavating in the Mediterranean. Taking samples in museums and at archaeological excavations was achieved by obtaining permits from the relevant authorities of each country. In Greece, in particular, the British School at Athens helped us enormously in negotiations with the authorities.

For the next 20 years (until 2001), we extended the range of our surveys of metal deposits in the Aegean and the wider Mediterranean, in Spain, Italy, Bulgaria and Timna (Israel), mapping their lead isotope ratio compositions and sampling metals from archaeological sites to examine the time sequence of exploitation of various ore sources of lead, silver, copper and (to a very limited extent) tin in the Mediterranean in 3rd-1st millennia BC. At the same time, the analysis of ore and slag samples was aimed at examining the characteristics of the lead isotope fingerprints of various mineralogical formations, checking for possible 'overlaps' and the methodology of interpretation of the data. The latter in particular became more and more complicated with the increase in the number of data for comparisons. The use of statistics was widely discussed, carefully examined and eventually discarded because of the lack of evidence for the lead isotope data of minerals in one geologically uniform deposit being normally distributed (Baxter and Gale 1998; Baxter et al. 2000). Also, in the majority of cases, the numbers of samples of ores characterising one deposit available for comparisons were too small for statistically valid analysis.

Until 1988, we were using a single collector, single source TIMS machine for the analytical work that was capable of analysing only about six samples in a working day. The relatively primitive preparative sample chemistry then in use took much longer: from about six samples a day for high lead samples to six samples a week for copper ores and slags. In 1989, we received a UK Science Research Council grant and bought one of the earliest multi-collector TIMS machines that was capable of producing data for 10 12 samples a day. Unfortunately, for various reasons, this instrument was not fully operational until 1994. The Research Council and British Academy grants that we obtained during that time allowed for the construction of new over-pressured low blank laboratories, the development of superior low blank methods of extractive chemistry (e.g. Gale 1996) and the employment of more laboratory staff, so 
that our output of lead isotope data increased rapidly in the last years of existence of the Isotrace Laboratory.

Since 1988, we started recording all new lead isotope, instrumental neutron activation analysis (INAA) and X-ray fluorescence analysis (XRF) data obtained on samples in the Isotrace Laboratory using the Borland computer database PARADOX ${ }^{\circledR}$. This database was gradually updated also with the analytical data obtained before 1988 at the Geological Age and Isotope Research Laboratory in the Department of Geology and included some important lead isotope data published by other teams (for example for Turkey, the Middle East, Germany, France, Italy, British Isles). This digital database currently consists of more than 3,300 lead isotope data for ores and slags and over 5,500 for various archaeological artefacts. The majority of the metal artefacts from Bronze Age contexts were also analysed for their chemical composition using either INAA, $\mathrm{XRF}$ or electron microprobe analysis.

\section{The Oxford archaeometallurgical surveys (in chronological order)}

Greece (1979-1996)

All surveys in Greece were made possible by geologists from the IGME. In particular, we collaborated in the earlier years with the IGME chief chemist Ms. Artemis Papastamataki who had excellent knowledge of the ancient copper slag heaps scattered from the Rhodope Mountains to the Cyclades, and later with Dr. Stavros
Papastavrou, whose geological knowledge of the Cyclades and Mainland Greece including Lavrion was of paramount importance. We also had the generous collaboration of various IGME geologists for surveys in Euboea, in the Othrys Mountains, in the Peloponnese, and in Crete, and of the chief chemist of the National Archaeological Museum, Athens, Dr. Eleni Mangou.

The mines of Lavrion were of particular interest because of the large size of this deposit, the variety of mineral types and their proven ancient exploitation in the Archaic/ Classical periods. During our surveys, it became apparent that the mines of Lavrion were capable of providing not only rich lead/silver ores to the prehistoric miners but also rich-oxidised copper ores (see Gale et al. 2009; Lapis 1999). In particular, the mine of Kamareza, which we visited in the early 1980s was still showing abundant mineralization of azurite and malachite that was sold in the souvenir shops of the port of Lavrion. To obtain as complete information as possible about the lead isotope characteristics of the minerals from Lavrion, we have analysed a large number of ores, as well as samples of lead and litharge from the archaeological excavations of 5th c. $\mathrm{BC}$ silver extraction sites in Thorikos and Agrileza. The numbers and types of samples analysed are listed in Table 3 .

In 1996, we published a preliminary Aegean lead isotope database as the third Isotrace Laboratory database (StosGale et al. 1996). This database does not include all of the data from Greece that is in our records. It was numbered as part 1 and included 262 lead isotope data from Lavrion, Thasos and the Cyclades. The numbers of data do not represent the size or importance of the mineralization. The

Table 3 List of samples of ores from the mines of Lavrion, silver extraction debris from the 5th c. BC site in Agrileza and Greek silver coins from the Athenian mints that were analysed for their lead isotope composition in Oxford

\begin{tabular}{llll}
\hline Region & Name of the location & Type & $\begin{array}{l}\text { Numbers of samples } \\
\text { analysed for LI }\end{array}$ \\
\hline Attica, Lavrion & Agrileza & Limonite/galena & 6 \\
& Esperance & Galena & 3 \\
& Kamareza & Malachite, azurite, galena, cerussite & 71 \\
& Megala Pefka & Galena & 2 \\
& Plaka & Galena, malachite/azurite & 55 \\
& Soureza & Limonite, galena & 5 \\
& Sounion & Galena & 1 \\
& Various & Galena (from IGME) & 2 \\
& Zastena & Galena & 160 \\
Total & Agrileza, 5th c. BC archaeological site of & Lead + Litharge & $24+5$ \\
& silver extraction & & $35+5$ \\
& Thorikos 5th c. BC archaeological mine & Lead + Litharge & 69 \\
& and washery by the amphitheatre & & 27 \\
\hline
\end{tabular}


comparatively large number of analysis of galenas from Kea (62), Seriphos (36), Kythnos (13) or Thera (17) are the result of the methodological study of the range of lead isotope ratios existing in these small occurrences, together with investigation of the possibility of distinguishing between them. So far, we have not had the opportunity to publish Part 2 which would include comprehensive data for all ores in Greece that was obtained in Oxford in the years 1976-2001. Some of that data was, however, published in various archaeological journals and conference proceedings, for example Kythnos copper slags and ores (Stos-Gale 1998), Crete copper and lead ores (Stos and Gale 2006), but the data from Chalkidiki, Macedonia, Othrys Mountains, Peloponnese, Pelion, Thrace and Rhodopi, in total 196 samples remains for the most part unpublished. All these areas are important for the ancient European metallurgy, because there is a considerable number of undated ancient slag heaps, both copper and lead, in all these localities (e.g. see Papastamataki 1984, 1985). Particularly important discoveries were our dating of copper smelting at Chrysokamino in Crete to the Bronze Age (Stos-Gale 1998) and the proof that Early Bronze Age smelting of copper at Raphina in Attica used copper ores from Lavrion (Gale et al. 2008).

\section{Cyprus (1982-1999)}

Cyprus was a very important locality for research into the Bronze Age metal trade; therefore, we made many trips to this island, working with the archaeologists (Karageorghis, Alison South, Webb, Åström, Coleman, Faschnacht), metallurgists (Zwicker, Tylecote) and geologists (Panayiotou and Constantinou of the Cyprus Geological Survey; Maliotis of the Hellenic Mining Company). In 1997 (Stos-Gale et al. 1997; Gale et al. 1997), the database of lead isotope compositions of ores was published, and in 1998, a summary of the data on copper slags was reported (Stos-Gale et al. 1998a). Currently, there are 430 data recorded for ores from the mines and slags from the slag heaps found in Cypriot fields and woods. Additionally, we have analysed a number of slags from the Bronze Age sites of Alambra, Apliki, Enkomi and Ayios Dhimitrios Kalavassos (26 samples in total). A preliminary list of analysed Bronze Age Cypriot metal artefacts was published in 1994 (Stos-Gale and Gale 1994), but a large number of metals from various sites (Lapithos, Kition, A. Iakovos, Nitovikla, etc.) still awaits publication. In view of the new analyses of ores published after 1994 (Gale et al. 1997), all data for Cypriot metal artefacts should be reinterpreted, though this does not apply to the copper oxhide ingots whether found in Cyprus or elsewhere in the Mediterranean. A major triumph of lead isotope provenancing has been the discovery that all post 1400 BC copper oxhide ingots, whether found in Cyprus, Sardinia, Mycenae, Crete, or shipwrecks such as Cape
Gelidonya, etc., were made from copper coming from the Apliki copper deposits in Cyprus (Stos-Gale et al. 1997; Gale 1999, 2009; Gale and Stos-Gale 2005).

\section{Timna (1982)}

In the Spring of 1982, Professor Beno Rothenberg invited us to visit his excavations of copper mines in Timna, Israel. During the visit there, we collected a number of samples of ores and slags and some samples of copper and iron artefacts augmented later by samples from Dr. Paul Craddock in the British Museum. Since we never had any funding directly for the characterisation of this deposit, only a few lead isotope analyses of this material were done in Oxford (68 ore samples). In view of the geology of this mineralisation (see Hauptmann 2007), this is not really sufficient for a full lead isotope characterisation of this important ancient mine. On the other hand, collaboration with Rothenberg gave us an opportunity to experiment with lead isotope analyses for provenancing iron metal artefacts found in Timna (Gale et al. 1990). We analysed seven iron and 26 copper artefacts excavated on this site.

Spain (1988)

A short archaeometallurgical survey in Spain was initiated and organised for us by the excavator, Robert Chapman, of the Bronze Age site Gatas in the south-east part of the country. We collected samples from 12 localities; additionally, we received some samples of ores from Rio Tinto from Rothenberg. We did not see any 'ancient' slag heaps in this region and many of the small galleries on the Gatas peninsula were clearly relatively modern, one can say perhaps exploratory, mining activities. The copper occurrences in the Sierras Almagro and Cabrera seemed more interesting, but the lack of any metal smelting activities was not consistent with pre-Roman mining practices. The majority of the lead isotope data of minerals from these mines were published in the Archaeometry database (Stos-Gale et al. 1995).

Another set of data from copper slags and ores from Andalusia was produced in our laboratory by Dr. Marcos Hunt Ortiz (2003). We also collected samples of Bronze Age artefacts from various sites, for which lead isotope analyses were published by Stos-Gale (2001). Brenda Rohl, also working in our laboratory, analysed for Beno Rothenberg 87 samples of silver extraction debris (lead, litharge, ore and speiss) from the excavations in Monte Romero, Rio Tinto and Corta Lago.

Italy (1985-1992)

In view of the importance of the origin of the late Bronze Age 'oxhide' ingots (Gale 1991) and the interest in the 
Nuragic metallurgy on Sardinia, we conducted three short archaeometallurgical surveys on this island with the guidance of Fulvia Lo Schiavo and geologists both from AGIP and from the Soprintendenza per i Beni Archeologici per le province di Sassari e Nuoro.

Nearly all results of the lead isotope analyses for ores collected during these surveys were published in the Archaeometry LI database (Stos-Gale et al. 1995). Additional data from the copper mines of Calabona, Capo Marargiu and Castello di Bonvei were published (Gale 1999, 2006). In total, we analysed at Oxford 266 samples of lead and copper ores from Sardinia and 339 samples of copper based artefacts from the Nuragic sites.

With the help of the geologists from AGIP (in particular Vincenzo Naso), we also surveyed copper and lead mines in Tuscany and mines in Liguria with Roberto Maggi. There was considerable difficulty in finding good samples of copper minerals in both of these localities; therefore, most of the LI data for the Tuscan mines was made on coexisting galena samples. Only in the Montecatini mine were we able to collect excellent azurite and malachite from the remains of minerals mined during the last years of the operation of the old shafts in this mine. This mine was quite memorable, because the entrance to the galleries was through the well-preserved early nineteenth century building of the mine office. From Roberto Maggi, we also had a number of samples of copper-based artefacts from Ligurian archaeological sites that were also analysed for their lead isotope composition (Campana et al. 1996).

\section{Bulgaria (1990-1994)}

Our survey of Bulgarian copper and lead mines and ancient slag heaps was jointly funded by the British Academy and the Bulgarian Academy of Sciences and organised by the archaeologists and geologists from the Bulgarian Academy of Sciences (Stos-Gale et al. 1998b). This project was directed towards the earliest Balkan metallurgy and aimed in particular at comparisons of the lead isotope compositions of the ores from the well-described prehistoric mine of Ai Bunar and copper artefacts from the Varna cemetery (Gale et al. 1991, 2000, 2003). We collected samples of ores from most mines and occurrences in central and southeastern Bulgaria listed by Chernykh (1978a, b). The mines in Central Bulgaria were mostly not very impressive. On the other hand, the copper mines of Ai Bunar, Varly Briag and some other mines in the south east showed considerable potential as sources of copper in antiquity, though our lead isotope analyses showed that no prehistoric artefacts from Bulgaria or Serbia were obtained from smelting ores from Ai Bunar. In the fields and woods of the eastern Rhodope we have seen huge amounts of copper slags of unknown age in the vicinity of galleries. Certainly, this part of Bulgaria should be further investigated from the point of archaeometallurgy.

The British Isles

Brenda Rohl worked for her D. Phil. in the Isotrace Laboratory on a project concerned with the early metallurgy of the British Isles. She published her database of lead isotope data on British ores as the second in the Archaeometry database series in 1996 (Rohl). The data were interpreted in great detail by Rohl and Needham (1998).

\section{Current state of the Oxford lead isotope digital database}

Apart from the data for ore deposits, the Oxford lead isotope digital database (OXALID) database contains many data for ancient metals, glass, paint and pigments. All data obtained in the Isotrace Laboratory (and earlier by N.H. Gale and V.E. Chamberlain) are at present kept in PARADOX ${ }^{\circledR}$ data tables. These tables were devised some 20 years ago, and data were entered into them over 15 years by various members of our research group. The result of these two factors is lack of full and coherent information about the samples in the database; each time when a group of data is being prepared for publication, it is necessary to cross-reference the information about the samples with our sampling and field notebooks. For this reason, the database cannot be made fully accessible to other researchers in its current form. Until now, one of us has had to answer any specific questions related to this database. We believe that these data are a valuable resource for researchers who are currently using the lead isotope method for archaeological provenance studies. Various groups and numbers of samples analysed at Oxford and some that were analysed in other laboratories, but were entered on the digital database in Oxford, are briefly listed in Tables 4, 5, 6 and 7.

\section{Conclusions}

The aim of this paper is to provide the twenty-first century reader with an overview of the methodology and the results of research in the application of lead isotopes for the provenance studies of ancient materials carried out at Oxford over a period of 27 years (1975-2002). This work started as an application of isotope geochemical methods to the study of ancient materials and has resulted in detailed methodology and basic scientific verification of the possibilities of its use in archaeological and art historical projects. The results of this work provide an important resource for future projects in this field. 
Table 4 Lead isotope analyses of copper and lead ores and slags for the Mediterranean

\begin{tabular}{llc}
\hline Country & Region & Total on the dbase \\
\hline Greece & Aegean Islands & 444 \\
Greece & Mainland & 353 \\
Greece & Crete & 61 \\
Cyprus & Troodos & 430 \\
Near East & Iran & 96 \\
Turkey & Ergani & 60 \\
Spain & Menorca \& South & 101 \\
Italy & Sardinia, Elba, Liguria & 332 \\
Bulgaria & South-East & 147 \\
& Total & 2,024 \\
\hline
\end{tabular}

Over the past 20 years, some archaeometrists have persistently raised objections to lead isotope provenance studies. Some of these were justified and resulted in moving forward the methodology by testing new approaches to data collection and interpretation. Others persist in the literature as mistaken approaches, often advanced by researchers not at all familiar with isotope geology. Some years ago, Tite, one of the founders and pillars of archaeometry, tried to bring some objectivity to the debate raging at the time by publishing a paper in defence of lead isotope provenance studies. There, he wrote: "The recent Antiquity paper by Budd et al. (1996), 'Rethinking the quest for provenance', is the latest in a series of polemical papers on archaeometallurgy by the Ancient Metallurgy Research Group at Bradford. Having started with the appearance of arsenical copper in Britain in the Early Bronze Age (Budd et al. 1992), this series has now moved on to the application of lead isotope analysis to copper provenance studies. These papers contain very little, if any, new scientific data but instead attack established procedures and interpretations." (Tite 1996). And further he adds:

Table 5 Lead isotope analyses of archaeological metal artefacts for the Bronze Age Mediterranean project

\begin{tabular}{llc}
\hline Country & Region & Total on the dbase \\
\hline Greece & Aegean Islands & 541 \\
Greece & Mainland & 819 \\
Greece & Crete & 694 \\
Cyprus & North \& South & 375 \\
Near East & Egypt, Israel, Syria & 451 \\
Turkey & Aegean coast, shipwrecks & 905 \\
Spain & South and Menorca & 219 \\
Italy & Sardinia & 339 \\
Bulgaria & South-East & 329 \\
Total & & 4,672 \\
\hline
\end{tabular}

Table 6 Miscellaneous ores analysed in Oxford and in other laboratories entered on the database

\begin{tabular}{lc}
\hline Deposits & Number of samples \\
\hline British Isles & 464 \\
Irish Cu ores & 11 \\
Turkey & 307 \\
Germany, Austria Bohemia & 464 \\
India and Iran & 70 \\
Red Sea region & 74 \\
Total & 1,390 \\
\hline
\end{tabular}

"Although papers criticising earlier work can play an important role in advancing a subject, it is crucial that such papers provide a balanced overview of the current state of research. An excess of partisan papers, attacking what are essentially 'straw men', risks bringing lead isotope analyses, and indeed archaeological science itself, into disrepute and is thus a disservice to the subject."

Unfortunately, the science on which lead isotope provenance studies are based is still being misinterpreted by some (see, for example, the errors pointed out in this paper which appear in Pollard and Heron 2008); therefore, the authors of this paper believe that it might be beneficial for the archaeological and archaeometric community to establish a web-based lead isotope forum led by the scientists with hands on experience of isotope geology. We would like to contribute our research experience and the OXALID database to such a forum.

It is hoped that the researchers who are now interested in using this method will take into account our experience and will use the OXALID database for their research if appropriate. We feel that, together with other scientists who worked on similar research projects, we have started a

Table 7 Miscellaneous ancient artefacts analysed at Oxford and in other laboratories entered on the database

\begin{tabular}{lc}
\hline Context & Number of samples \\
\hline British Roman and Mediaeval lead & 100 \\
Glass: Roman and Mediaeval & 131 \\
Glaze: Islamic and Roman & 100 \\
Greek silver coins & 111 \\
German silver coins & 34 \\
Hacksilber & 133 \\
Roman bronzes and lead & 110 \\
Metals from a Polish site c.200 AD & 34 \\
Sasanian silver & 105 \\
Iron Age Swiss copper based metals & 60 \\
Pigments & 73 \\
Total & 991 \\
\hline
\end{tabular}


valuable scientific path for answering some of the difficult questions concerning the history of the technological development of humanity. This work is by no means complete and we hope that others will carry on with new developments, as indeed seems to be happening. The MCICPMS instruments currently used in geological laboratories can provide lead and other isotope data on a range of materials with much greater expediency.

Acknowledgements The research in the Isotrace Laboratory was based on the hard work of a great team of chemists and technicians: Valerie Chamberlain (geologist), Judy Houghton, Brenda Rohl, Nick Annets, Melanie Jones, Bob Speakman, Andrew Shortland and Neil Boulton. Research at Oxford was generously supported for over 25 years by many donors: the Stifftung Volkswagenwerk, the Leverhulme Trust, UK Science Research Councils (SERC and NERC), the Institute of Aegean Prehistory NY (INSTAP), the British and Bulgarian Academies and the University of Oxford. Our geological surveys in the Eastern Mediterranean were possible thanks to the Institute of Geological and Mineralogical Exploration, Athens (IGME) and the Hellenic Mining Company (Cyprus), and the time and expertise of numerous geologists, in particular Dr. Stavros Papastavrou and Dr. George Maliotis. Sampling of the artefacts was possible thanks to the permission of the various national organisations guarding their Cultural Heritage and countless archaeologists generous with their time and expertise. We thank Professor A. L. Burke and two anonymous referees for very helpful reviews of this paper.

\section{References}

Arden JW, Gale NH (1974) A new electrochemical technique for the separation of lead at trace levels from natural silicates. Analytical Chemistry 46:2-9

Baker J, Stos S, Waight T (2006) Lead isotope analysis of archaeological metals by multiple-collector inductively coupled plasma mass spectrometry. Archaeometry 48(1):45-56

Barnes HL (1979) Geochemistry of hydrothermal ore deposits. Wiley Interscience, New York

Barnes IL, Murphy TJ, Gramlich JW, Shields WR (1973) Lead separation by anodic deposition and isotopic ratio mass spectrometry of microgram and smaller quantities. Analytical Chemistry $45: 1881-1884$

Barnes IL, Shields WR, Murphy TJ, Brill RH (1974) Isotopic analysis of Laurion lead ores. In: Advances in Chemistry Series, No 138. American Chemical Society, Washington, pp 1-10

Barnes IL, Gramlich JW, Diaz MG, Brill RH (1978) The possible change of lead isotope ratios in the manufacture of pigments: a fractionation experiment. In: Carter GF (ed) 'Archaeological chemistry II', Advances in chemistry series 171: 273-277. American Chemical Society, Washington

Baxter MJ (1999) On the multivariate normality of data arising from lead isotope fields. Journal of Archaeological Science 26(1):117-124

Baxter MJ (2003) Statistics in archaeology. Arnold, London

Baxter MJ, Gale NH (1998) Testing for multivariate normality via univariate tests: a case study using lead isotope ratio data. Journal of Applied Statistics 25(5):671-683

Baxter MJ, Beardah CC, Westwood S (2000) Sample Size and Related Issues in the Analysis of Lead Isotope Data. Journal of Archaeological Science 27:973-980

Begemann F, Kallas K, Schmitt-Strecker S, Pernicka E (1999) Tracing ancient tin via isotope analyses, in A. Hauptmann, Th. Rehren, E.
Pernicka and Ü. Yalcin (eds.) 'The Beginnings of Metallurgy'. Der Anschnitt Beiheft 9:277-284

Belshaw NS, Freedman PA, O’Nions RK, Frank M, Guo Y (1998) A new variable dispersion double-focusing plasma mass spectrometer with performance illustrated for $\mathrm{Pb}$ isotopes. International Journal of Mass Spectrometry 181:51-58

Brill RH (1969) Lead isotopes in ancient glass, Ann. Congr. Journées Int. Verre, 4th. (International Association for the History of Glass). Liège, pp 255-261

Brill RH, Wampler JM (1965) Isotope studies of ancient lead. American Journal of Archaeology 69:165-166

Brill RH, Wampler JM (1967) Isotope studies of ancient lead. American Journal of Archaeology 71:63-77

Budd P, Gale DM, Pollard AM, Thomas RG, Williams PA (1992) The early development of metallurgy in the British Isles. Antiquity 66:677-86

Budd P, Gale D, Pollard AM, Thomas RG, Williams PA (1993) Evaluating lead isotope data: some further observations. Archaeometry 35:241-263

Budd P, Pollard AM, Scaife B, Thomas RG (1995a) The possible fractionation of lead isotopes in ancient metallurgical processes. Archaeometry 37:143-150

Budd P, Haggerty A, Pollard AM, Scaife B, Thomas RG (1995b) New heavy isotope studies in archaeology. Israel Journal of Chemistry 35:125-130

Budd P, Pollard AM, Scaife B, Thomas RG (1995c) Oxhide ingots, recycling and the Mediterranean metals trade. Journal of Mediterranean Archaeology 8:1-32

Budd P, Haggerty A, Pollard AM, Scaife B, Thomas RG (1996) Rethinking the quest for provenance. Antiquity 70:168-174

Cameron AE, Smith DH, Walker RE (1969) Mass spectrometry of nanogram-size samples of lead Anal. Chem. 41:525-526

Campana N, Maggi R, Stos-Gale ZA, Houghton J (1996) Miniere e metallurgia in Liguria fra IV millenio e IV secolo B.C. In: 'La Miniera l'uomo el'ambiente.' Convegno di Studi - Cassino, 2-4 giugno 1994. All'insegna del Giglio. Firenze, pp 15-52

Catanzaro EJ (1967a) Absolute isotopic abundance ratios of three common lead reference samples. Earth and Planetary Science Letters 3:343-346

Catanzaro EJ (1967b) Triple filament method for solid-sample lead isotope analysis. Journal of Geophysical Research 72:1325-1330

Catanzaro EJ, Murphy TJ, Shields WR, Garner EL (1968) Absolute isotopic abundance ratios of common, equal-atom and radiogenic lead isotopic standards. Journal of Research of the National Bureau of Standards 72A:261-267

Chamberlain V, Gale NH (1980) The isotopic composition of lead in Greek coins and in galena from Greece and Turkey. In: Slater EA, Tate JO (eds) Proceedings of the 16th International Symposium on Archaeometry and Archaeological Prosepection, Edinburgh 1976. The National Museum of Antiquities of Scotland, pp 139-155

Chernykh EG (1978a) Gornoe Delo I Metallurgia v Drevneishi Boulgarii, Sofia

Chernykh EG (1978b) Aibunar - a Balkan copper mine of the fourth millennium BC, Proceedings of the. Prehistoric Society 44:203-217

Cherry JF, Knapp AB (1991) Quantitative provenance studies and Bronze Age trade in the Mediterranean: some preliminary reflections. In: Gale NH (ed) Bronze age trade in the Mediterranean. SIMA XC, Paul Åströms Forlag, Jonsered, pp 92-120

Conophagos CE (1980) Le Laurium Antique. Ekdotike Hellados, Athens

Farquhar RM, Fletcher IR (1980) Lead isotope identification of sources of galena from some prehistoric Indian sites in Ontario, Canada. Science 207:640-643

Farquhar RM, Fletcher IR (1984) The provenience of galena from Archaic/Woodland sites in North America: Lead isotope evidence. Americaan Antiquity 49(4):774-785 
Farquhar RM, Walthall JA, Hancock RGV (1995) 18th century lead smelting in central north America: Evidence from lead isotope and INAA measurements. Journal of Archaeological Science 22 (5):639-648

Faure G (1986) Principles of isotope geology. Wiley, New York

Fischer-Bossert W (2008) The Athenian Decadrachm, Numismatic notes and monographs No. 168. American Numismatic Society, New York

Gale NH (1979) Lead isotopes and Archaic Greek silver coins. Archaeophysica 10. Rheinisches Landesmuseum Bonn, pp 194208

Gale NH (1980) Some aspects of lead and silver mining in the Aegean. In: Doumas C (ed) Thera and the Aegean World II. Thera and the Aegean World, London, pp 161-196

Gale NH (1981) Mediterranean obsidian source characterization by strontium isotope analysis. Archaeometry 23:41-51

Gale NH (1989) Lead isotope analyses applied to provenance studies a brief review. In: Maniatis Y (ed) Archaeometry. Elsevier, Amsterdam, pp 469-502

Gale NH (1991) Copper Oxhide ingots: their origin and their place in the Bronze Age Metals Trade in the Mediterranean. In: Gale NH (ed) Science and archaeology: bronze age trade in the Mediterranean', Studies in Mediterranean Archaeology XC. P. Åstroms Förlag, Goteborg, pp 197-239

Gale NH (1996) A new method for extracting and purifying lead from difficult matrices for isotopic analysis. Analytica Chimica Acta 332(1):15-21

Gale NH (1997) The isotopic composition of tin in some ancient metals and the recycling problem in metal provenancing. Archaeometry 39:71-82

Gale NH (1998) The role of Kea in metal production and trade in the late Bronze Age. In: Mendoni LG, Mazarakis-Ainian A (eds) Proceedings of the 1994 International Symposium Kea-Kythnos: historical and archaeological researches, Meletemata 27. National Hellenic Research Foundation, Athens, \& Diffusion de Boccard, Paris, pp 737-758

Gale NH (1999) Lead isotope characteristics of the ore deposits of Cyprus and Sardinia and its application to the discovery of the sources of copper for Late Bronze Age oxhide ingots. In: Young SMM, Pollard AM, Budd P, Ixer RAF (eds) Metals in Antiquity, BAR International Series 792. Archaeopress, Oxford, pp 110 133

Gale NH (2005) Die Kupferbarren von Uluburun Teil 2: Bleiisotopenanalysen von Bohrkernen aus den Barren. In: Yalcin Ü, Pulak C, Slotta R (eds) Das Schiff von Uluburun. Deutsche BergbauMuseum, Bochum, pp 141-147

Gale NH (2006) Lead isotope studies-Sardinia and the Mediterranean: Provenance studies of artefacts found in Sardinia. Instrumentum 23:29-34

Gale N (2009) Copper Oxhide Ingots and lead isotope provenancing. In: Betancourt PP, Ferrence SC (eds) Metallurgy: understanding how learning why, studies in honor of James D. Muhly. INSTAP Academic Press, Philadelphia in press

Gale NH, Stos-Gale ZA (1981a) Lead and silver in the ancient Aegean. Scientific American 244(6):176-192

Gale NH, Stos-Gale ZA (1981b) Cycladic lead and silver metallurgy. Annual of the British School at Athens 76:169-224

Gale NH, Stos-Gale ZA (1982) Bronze Age copper sources in the Mediterranean: A new approach. Science, Vol. 216:11-19

Gale NH, Stos-Gale ZA (1992) Lead isotope studies in the Aegean the British Academy Project. In A.M. Pollard (ed.) 'Advances in Archaeological Science'. Proceedings of the British Academy 77:63-108

Gale NH, Stos-Gale ZA (1996) Lead isotope methodology: the possible fractionation of lead isotope compositions during metallurgical processes. In: Demirci S, Ozer AM, Summers GD (eds) Archaeometry 94 - The Proceedings of the 29th International Symposium on Archaeometry. Ankara, pp 287-299

Gale NH, Stos-Gale ZA (2000) Lead isotope analyses applied to provenance studies. In: Ciliberto E, Spoto G (eds) Modern analytical methods in art and Archaeology. Wiley, New York, pp 503-584

Gale NH, Stos-Gale ZA (2005) Zur Herkunft der Kupferbarren aus dem Schiffswrack von Uluburun und der spätbronzezeitliche Metallhandel im Mittelmeeraum. In: ؟a1çin Ü, Pulak C, Slotta R (eds) Das Schiff von Uluburun. Bochum, pp 117-132

Gale NH, Gentner W, Wagner GA (1980) Mineralogical and geographical sources of Archaic Greek coinage. In: Metcalf DM, Oddy WA (eds) Metallurgy in numismatics, 1. Royal Numismatic Society, London, pp 3-49

Gale NH, Stos-Gale ZA, Davis JL (1984) The Provenance of Lead Used at Ayia Irini, Keos. Hesperia 53(4):389-406

Gale NH, Bachmann HG, Rothenberg B, Stos-Gale ZA, Tylecote RF (1990) The adventitious production of iron in the smelting of copper in Timna, Wadi Arabah. In: Rothenberg B (ed) Ancient Metallurgy in Timna. Thames and Hudson, London, pp 182-190

Gale NH, Stos-Gale ZA, Lilov P, Dimitrov M, Todorov T (1991) Recent studies of eneolithic copper ores and artefacts in Bulgaria. In: Mohen J-P, Éluère C (eds) Découverte du Métal. Picard, Paris, pp 49-76

Gale NH, Stos-Gale ZA, Maliotis G, Annetts N (1997) Lead isotope data from the Isotrace Laboratory, Oxford: Archaeometry data base 4, ores from Cyprus. Archaeometry 39(1):237-246

Gale NH, Woodhead AP, Stos-Gale ZA, Walden A, Bowen I (1999) Natural variations detected in the isotopic composition of copper: possible applications to archaeology and geochemistry. International Journal of Mass Spectrometry and Ion Processes 184:1-9

Gale N, Stos-Gale S, Radountcheva A, Ivanov I, Lilov P, Todorov T, Panayotov I (2000) Early metallurgy in Bulgaria. Godishnik Nov Bulgarski Universitet IV-V:102-68

Gale N, Stos-Gale S, Raduncheva A, Ivanov I, Lilov P, Todorov T, Panayotov I (2003) Early metallurgy in Bulgaria. In: Craddock P, Lang $\mathrm{J}$ (eds) Mining and metal production through the ages. British Museum Press, London, pp 122-173

Gale NH, Kayafa M, Stos-Gale ZA (2008) Early Helladic metallurgy at Raphina, Attica and the role of Lavrion. In: Tzachili I (ed) Aegean Metallurgy in the Bronze Age. Ta-Pragmata, Athens, pp 87-104

Gale NH, Kayafa M, Stos-Gale ZA (2009) Further evidence for Bronze Age production of copper from ores in the Lavrion ore district, Attica, Greece. In: Giumlia-Mair A, Rehren Th (eds) Proceedings of the 2nd. International Conference Archaeometallurgy in Europe 2007, Aquileia, AIM/Milan, in press

Gerstenberger H, Haase G (1997) A highly effective emitter substance for mass spectrometric $\mathrm{Pb}$ isotope ratio determinations. Chemical Geology 136:309-312

Grögler N, Geiss J, Grünenfelder M, Houtermans FG (1966) Isotopenuntersuchungen zur Bestimmung der Herkunft römischer Bleirohre und Bleibarren. Zeitschrift für Naturforschung 21a:1167-72

Gulson BL (1986) Lead isotopes in mineral exploration. Elsevier, Oxford

Gulson BL, Mizon KJ (1979) Lead isotopes as a tool for gossan assessment in base metal exploration. Geochemical Exploration 11:299-320

Härke H (1978) Probleme der optischen Emissionsspektralanalyse in der Urgeschichtsforschung. Prähistorische Zeitschrift 53:165-276

Hart SR, Shimizu N, Sverjensky DA (1981) Lead isotope zoning in galena: an ion microprobe study of a galena crystal from the Buick mine. Southeast Missouri, Economic Geology 76:1873-1878

Hauptmann A (2007) The Archaeometallurgy of copper. Springer, Berlin 
Hauptmann A, Begemann F, Heitkemper E, Pernicka E, SchmittStrecker S (1992) Early copper produced at Feinan. Wadi Arabah, Jordan: The composition of ores and copper, Archeomaterials $6: 1-33$

Hirata T (1996) Lead isotopic analyses of NIST standard reference materials using multiple collector inductively coupled plasma mass spectrometry coupled with a modified external correction method for mass discrimination effect. The Analyst 121:14071411

Hunt Ortiz MA (2003) Prehistoric mining and metallurgy in the South West Iberian Peninsula, BAR S1188. Archaeo, Oxford

Junghans S, Sangmeister E, Schröder M (1960) Metallanalysen kupferzeitlicher und frühbronzezeitlicher Bodenfunde aus Europa. Gebr, Mann

Junghans S, Sangmeister E, Schröder M (1968) Kupfer und Bronze in der frühen Metallzeit Europas 1-3. Gebr, Mann

Junghans S, Sangmeister E, Schröder M (1974) Kupfer und Bronze in der frühen Metallzeit Europas 4. Gebr, Mann

Kraay CM (1976) Archaic and classical Greek coins Oxford

Lapis (1999) Lavrion, Griechenland, Lapis, Jg.24, Nr. 7/8. Juli/ August, Christian Weise Verlag/München

Macfarlane (1999) The lead isotope method for tracing the sources of metal in archaeological artefacts: strengths, weaknesses and applications in the Westrn Hemisphere. In: Young SMM, Pollard AM, Budd P, Ixer RAF (eds) Metals in antiquity, BAR International Series 792. Archaeo, Oxford, pp 310-316

Marinos G, Petrascheck W (1956) Laurium. Institute of geology and underground researches in Greece. Geological and Geophysical Research 4(1), Athens

McGeehan-Liritzis V, Pollard M (1986) A new look at Early Aegean metallurgy with the aid of the Computer. In: Liritzis Y, Hackens $\mathrm{T}$ (eds) Acts of the First South European Conference in Archaeometry, Delphi 1984. PACT Journal 15:33-40

McGill RAR, Budd P, Scaife B, Lythgoe P, Pollard AM, Haggerty R, Young SMM (1999) The investigation and archaeological implications of anthropogenic heavy metal isotope fractionation. In: Young SMM, Pollard AM, Budd P, Ixer RAF (eds) Metals in antiquity, BAR International Series 792. Archaeo, Oxford, pp 258-261

Muller O, Gentner W (1979) On the composition and silver sources of Aeginetan coins from the Asyut Hoard. Archaeophysica 10. Rheinisches Landesmuseum Bonn, pp 176-193

Mulliken RS, Harkins WD (1922) The separation of isotopes. Theory of resolution of isotopic mixtures by diffusion and similar processes. Experimental separation of mercury by evaporation $m$ a vacuum Journal of the American Chemical Society 44:37-65

Niederschlag E, Pernicka E, Seifert T, Bartelheim M (2003) The determination of lead isotope ratios by multiple collector ICP-MS: A case study of Early Bronze Age artefacts and their possible relation with ore deposits of the Erzgebirge. Archaeometry 45 (1):61-100

Noddack I, Noddack W (1934) Herkunftsuntersuchungen. Angewandte Chemie 74:637-41

Nowell G, Clayton R, Gale NH, Stos-Gale NH (2002) Sources of tin is isotopic evidence likely to help? In: Bartelheim M, Pernicka E, Krause R (eds) 'The Beginnings of Metallurgy in the Old World,' Forschungen zur Archäometrie und Altertumswissenschaft. Band 1, Verlag Marie Leidorf, Rahden/Westf, pp 291-302

Otto H, Witter W (1952) Handbuch der ältesten vorgeschichtlichen Metallurgie in Mitteleuropa. Barth Verlag, Leipzig

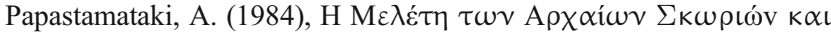
$\eta \Sigma v \mu \beta о \lambda \eta ́ ~ \tau o v \varsigma ~ \sigma \tau \eta v ~ A \pi о к \alpha ́ \lambda v \psi \eta ~ \tau \eta \varsigma ~ \Pi \alpha \lambda \alpha \iota-$

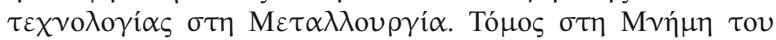

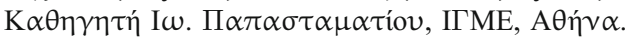

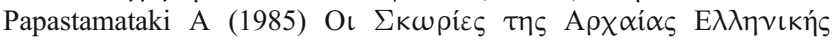

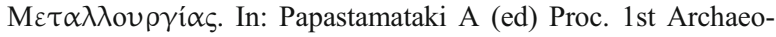

metric Conference on the Metal Slags of Ancient Greece, IGME Athens, pp 41-68

Pernicka E, Bachmann H-G (1983) Archäometallurgische untersuchungen zur antiken Silbergewinnung in Laurion III: Das Verhalten einiger Spurenelemente beim Abtreiben des Bleis. Erzmetall 36:592-597

Pernicka E, Seeliger TC, Wagner GA, Begemann F, Schmitt-Strecker S, Eibner C, Oztunali O, Baranyi I (1984) Archeometallurgische untersuchungen in Nordwestanatolien. Jahrbuch des RomischGermanischen Zentralmuseums Mainz 31:533-599

Pernicka E, Begemann F, Schmitt-Strecker S, Todorova H, Kuleff I (1997) Prehistoric copper in Bulgaria: its composition and provenance. Eurasia Antiqua 3:41-180

Pinarelli L (2004) Lead isotope characterisation of copper ingots from Sardinia (Italy): inferences on their origins. Bulletin of the Geological Society of Greece XXXVI:1173-1180

Pollard AM, Gale NH (1986) Computer studies of lead isotope data. Poster presented at the 25th. International Symposium on Archaeometry, Athens, 1986

Pollard AM, Heron C (2008) Archaeological chemistry, 2nd edn. RSC, London

Ponting M, Evans JA, Pashley V (2003) Fingerprinting of Roman mints using laser-ablation. Archaeometry 45:591-597

Price MJ, Waggoner NM (1975) Archaic Greek coinage: the Asyut hoard. Vecci, London

Rehkämper M, Halliday AN (1998) Accuracy and long-term reproducibility of lead isotopic measurements by multiple-collector inductively coupled plasma mass spectrometry using an external method for correction of mass discrimination. International Journal of Mass Spectrometry 181:123-33

Rehkämper M, Mezger K (2000) Investigation of matrix effects for $\mathrm{Pb}$ isotope ratio measurements by multiple collector ICP-MS: verification and application of optimized analytical protocols. Journal of Analytical Atomic Spectrometry 15:1451-1460

Rehren Th, Pernicka E (2008) Coins, artefacts and isotopes Archaeometallurgy and Archaeometry. Archaeometry 50 (2):232-248

Rohl BM (1996) Lead isotope data from the Isotrace Laboratory, Oxford: Archaeometry data base 2, galena from Britain and Ireland. Archaeometry 38(1):165-180

Rohl BM, Needham S (1998) The circulation of metal in the British Bronze Age: The application of lead isotope analysis, British Museum Occasional Paper No. 102. ISBN 086159102 X

Sayre EV, Yener KA, Joel EC, Barnes IL (1992) Statistical evaluation of the presently accumulated lead isotope data from Anatolia and surrounding regions. Archaeometry 34:73-105

Sayre EV, Joel EC, Blackman MJ, Yener KA, Ozbal H (2001) Stable lead isotope studies of Black Sea Anatolian ore sources and related Bronze Age and Phrygian artefacts from nearby archaeological sites. Appendix: new central Taurus ore data. Archaeometry 43:77-115

Scaife B, Budd P, McDonnell A, Pollard AM (1999) Lead isotope analysis, oxhide ingots and the presentation of scientific data in archaeology. In: Young SMM, Pollard AM, Budd P, Ixer RAF (eds) Metals in Antiquity, BAR International Series 792. Archaeo, Oxford, pp 122-133

Segal I, Halicz L (2005) Provenance studies in archaeometallurgy using lead isotope ratio determination by Q-ICP-MS and MCICP-MS. Israel J Earth Sci 54:87-96

Seltman C (1977) Greek coins. Spink, London

Snoek W, Plimer IR, Reeves S (1999) Application of Pb isotope geochemistry to the study of the corrosion products of archaeological artefacts to constrain provenance. Journal of Geochemical Exploration 66:421-425

Stos Z, Gale N (2006) Lead isotope and chemical analyses of slags from Chrysokamino. In Betancourt PP (ed) The Chrysokamino 
metallurgy workshop and its territory. Hesperia, Supplement 36. The American School of Classical Studies at Athens, pp 298-319

Stos-Gale ZA (1998) The role of Kythnos and other Cycladic islands in the origins of Early Minoan metallurgy. In Mendoni L, Mazarakis-Ainian A (eds) Meletimata 27, Kea-Kythnos: history and Archaeology: Proceeding of the Kea-Kythnos Conference, Kea June 1994. Diffusion de Boccard, Paris \& Athens, pp 717736

Stos-Gale ZA (2001) The development of Spanish metallurgy and copper circulation in Prehistoric Southern Spain. In: Gomez Tubio BM, Respaldiza MA, Luisa Pardo Rodriguez M (eds) III Congreso Nacional de Arqueometria. Secretariado de Publicaciones Universidad de Sevilla, Sevilla, pp 445-456

Stos-Gale ZA, Gale NH (1994) The origin of metals excavated on Cyprus, Chapter 3. In: Knapp B, Cherry J (eds) Provenance studies and Bronze Age Cyprus: production exchange and politico-economic change. Prehistory Press, Madison, pp 92122 and pp 210-216.

Stos-Gale ZA, Gale NH, Zwicker U (1986) The copper trade in the South East Mediterranean Region: preliminary scientific evidence. Reports of the Department of Antiquities Cyprus pp 73-88

Stos-Gale ZA, Gale NH, Houghton J, Speakman R (1995) Lead isotope analyses of ores from the Western Mediterranean. Archaeometry 37(2):407-415

Stos-Gale ZA, Gale NH, Annetts N (1996) Lead isotope analyses of ores from the Aegean - Part I. Archaeometry 38(2):381-390

Stos-Gale ZA, Maliotis G, Gale NH, Annetts N (1997) Lead isotope characteristics of the Cyprus copper ore deposits applied to provenance studies of copper oxhide ingots. Archaeometry 39 (1):83-124

Stos-Gale Z, Maliotis G, Gale NH (1998a) A preliminary survey of the Cypriot slag heaps and their contribution to the reconstruction of copper production on Cyprus. In Rehren T, Hauptmann A, Muhly J (eds) Metallurgica Antiqua. in Honour of Hans-Gert Bachmann and Robert Maddin. Deutches Bergbau Museum, Bochum, pp 235-262

Stos-Gale ZA, Gale NH, Annetts N, Todorov T, Lilov P, Raduncheva A, Panayotov I (1998b) Lead isotope data from the Isotrace Laboratory, Oxford: Archaeometry Database 5, Ores from Bulgaria. Archaeometry 40(1):217-226
Tite MS (1996) In defence of lead isotope analysis. Antiquity 70:95962

Todt W, Cliff RA, Hasner A, Hofmann AW (1996) Evaluation of a ${ }^{202} \mathrm{~Pb}-{ }^{205} \mathrm{~Pb}$ double spike for high-precision lead isotope analysis. In: Earth processes: reading the isotopic code. Geophysical Monograph 95. American Geophysical Union, Washington DC, p 429

Valera RG, Valera PG, Lo Schiavo F (2002) Lead in Nuragic Sardinia: ores, isotopy, and archaeology. In: Bartelheim M, Pernicka E, Krause R (eds) Die Anfange der Metallurgie in der Alten Welt/ The beginnings of metallurgy in the Old World. Archaometrie Freiberger Forschungen Zur Altertumswissenschaft1, pp 359-377

Wagner G-A, Weisgerber G (1979) The ancient silver mine at Ayios Sostis on Siphnos (Greece). Archaeophysica 10. Rheinisches Landesmuseum Bonn, pp 209-222

Wagner GA, Weisgerber G (eds) (1985) Silber, Blei und Gold auf Sifnos, prähistorische und antike Metallproduktion, Der Anschnitt, Beiheft 3. Deutsches Bergbau-Museum, Bochum

Wagner GA, Weisgerber G (eds) (1988) Antike Edel-und Buntmetallgewinnung auf Thasos, Der Anschnitt, Beiheft 6. Deutsches Bergbau-Museum, Bochum

Wagner GA, Storzer D, Keller J (1976) Spaltspurendatierungen quartärer Gesteingläser aus dem Mittelmeerraum. Neues Jahrbuch für Mineralogie, Monatshefte, pp 84-94

Wagner GA, Gentner W, Gropengiesser H, Gale NH (1980) Early bronze age lead-silver mining and metallurgy in the Aegean. In: Craddock PT (ed) Scientific studies in early mining and extractive metallurgy. British Museum Occasional Paper 20:6386

Wagner GA, Pernicka E, Seeliger T, Lorentz IB, Begemann F, SchmittStrecker SF, Eibner C, Oztunali O (1986) Geochemische und isotopische Characteristika früher Rohstoffquellen fur Kupfer, Blei, Silber und Gold in der Turkei. Jahrbuch des Römisch-Germanischen Zentralmuseums Mainz 33:723-752

Yi W, Budd P, McGill RAR, Young SMM, Halliday AN, Haggerty R, Scaife B, Pollard AM (1999) Tin isotope studies of experimental and prehistoric bronzes. In A. Hauptmann, Th. Rehren, E. Pernicka and Ü. Yalçin (eds.) 'The Beginnings of Metallurgy'. Der Anschnitt Beiheft 9:285-290 